\title{
Pengaruh Brand Image, Persepsi Harga dan Word Of Mouth Terhadap Keputusan Pembelian Konsumen The Highland Park Resort Hotel Bogor
}

\author{
Tjong Su Ling dan Anton Widio Pratomo
}

Program Studi Manajemen, Institut Bisnis dan Informatika Kesatuan

Bogor, Indonesia

E-Mail: tjongsuling16@gmail.com

Submitted: FEBRUARI 2020

\begin{abstract}
Competition is now increasingly fierce, making the company put orientation on customer satisfaction and satisfaction as the main goal. With more and more companies offering the same products and services to consumers, more and more alternatives are owned by consumers, so companies always try to meet the satisfaction of their customers. A good company image will make prospective customers more confident with the goods or services they will choose. The image will eventually become good, when consumers have enough memorable experience. WOM is a promotional activity that the level of control by marketers is very low but has an extraordinary impact on the company's products or services. WOM is able to spread so quickly if the individuals who spread it also have a wide network, news that is spread can be positive and negative news depending on what they feel when they enjoy the products or services offered. The purpose of this study is To find out and analyze the influence of Brand Image on Purchasing Decisions, To find out and analyze the effect of Price Perception on Purchasing Decisions, To find out and analyze the influence of Word of Mouth on Purchasing Decisions and To find out and analyze the effect of Brand Image, Price Perception, and Word of Mouth together on Purchasing Decisions. The number of respondents in this study amounted to 100 respondents taken from guests who have stayed at The Highland Park Resort Hotel Bogor. Research data were processed using SPSS. The results of this study are as follows: Brand Image has a positive and significant effect on purchasing decisions at The Highland Park Resort Hotel Bogor with a regression coefficient of 0.370 and a significant value of 0.017. Price perception has a positive and significant effect on Purchasing Decisions at The Highland Park Resort Hotel Bogor with a regression coefficient value of 0.312 and has a significant value of 0.001. Word of Mouth has a positive and significant effect on Purchasing Decisions at The Highland Park Resort Hotel Bogor with a regression coefficient of 0.576 and a significant value of 0,000. Brand Image, Price Perception, and Word of Mouth have a positive and significant effect on Purchasing Decisions at The Highland Park Resort Hotel Bogor with a calculated F value of 48.507 and greater than the F table of 2.70 and a significance value of 0,000.
\end{abstract}

Keywords: brand image, perceived price, WOM, Purchasing Decision

\section{PENDAHULUAN}

Sejalan dengan perkembangan dunia bisnis saat ini, maka semakin berkembangnya tingkat persaingan dalam pemenuhan kebutuhan manusia. Peran pemasaran semakin penting dalam suatu perusahaan, baik itu perusahaan yang menghasilkan barang maupun jasa. Pendekatan pemasaran tidak lepas dari sisi konsumen, sebab konsumen mempunyai peranan penting, dimana konsumen 
Tourism Customer Purchasing Decision

\section{2}

\section{JIPKES}

Jurnal Ilmiah Pariwisata Kesatuan

Vol. 1 No. 1, 2020

pp. $31-42$

IBI KESATUAN

E-ISSN XXXX - XXXX DOI: sebagai alat ukur dalam menentukan keberhasilan suatu barang atau jasa. Oleh sebab itu peran pemasaran bertujuan memuaskan kebutuhan manusia, dimana kebutuhan manusia akan bergerak dinamis sesuai dengan perkembangan sehingga para pelaku dunia bisnis harus peka membaca setiap perubahan selera konsumennya. Persaingan yang semakin ketat, menyebabkan suatu perusahaan menempatkan orientasi pada pemenuhan dan kepuasan pelanggan sebagai tujuan utama. Dengan semakin banyaknya perusahaan yang menawarkan produk dan jasa yang sama pada konsumen, maka semakin banyak pula alternatif yang dimiliki konsumen, sehingga perusahaan selalu berusaha memenuhi kepuasan pelanggan mereka.

Citra perusahaan yang bagus akan membuat calon konsumen semakin yakin dengan barang atau jasa yang akan mereka pilih. Citra akhirnya akan menjadi baik, ketika konsumen mempunyai pengalaman yang cukup berkesan. WOM merupakan aktivitas promosi yang tingkat pengendaliannya oleh pemasar sangat rendah tetapi memberikan dampak yang sangat luar biasa terhadap produk atau jasa perusahaan.

WOM mampu menyebar begitu cepat bila individu yang menyebarkannya juga memiliki jaringan yang luas, berita yang disebarkan dapat berupa berita Positif dan Negatif tergantung dari apa yang mereka rasakan pada saat menikmati Produk atau jasa yang ditawarkan.

Menurut Kotler (2011) jasa adalah setiap tindakan atau kinerja yang dapat ditawarkan oleh satu pihak kepada pihak lain yang secara prinsip tidak berwujud dan tidak menyebabkan perpindahan kepemilikan. Produksi jasa tidak dapat terikat atau tidak terikat pada suatu produk fisik. Merek adalah atribut yang dianggap penting terutama untuk menumbuhkan persepsi yang positif. Menurut Kotler \& Keller (2009) menyatakan bahwa merek adalah Nama, istilah, lambang, atau desain, atau kombinasinya, yang dimaksudkan untuk mengidentifikasi barang atau jasa dari salah satu penjual atau kelompok penjual dan mendiferensiasikan mereka dari pesaing.

Menurut Tjiptono (2014) keputusan pembelian adalah sebuah proses dimana konsumen mengenal masalahnya, mencari informasi mengenai produk atau merek tertentu dan mengevaluasi seberapa baik masing-masing alternatif tersebut dapat memecahkan masalahnya, yang kemudian mengarah kepada keputusan pembelian. Adapun indikator keputusan pembelian menurut kotler dan keller (2009)

1. Adanya kebutuhan

2. Pencarian informasi

3. Pertimbangan alternative lain

4. Keputusan pembelian

5. Pembelian ulang

Menurut Tjiptono (2015) "Citra merek adalah deskripsi asosiasi dan keyakinan konsumen terhadap merek tertentu. Citra merek (Brand Image) adalah pengamatan dan kepercayaan yang dingenggam konsumen, seperti yang dicerminkan di asosiasi atau di ingatan konsumen" Berdasarkan pengertian citra merek yang dikemukan para ahli diatas dapat diambil kesimpulan bahwa citra merek adalah asosiasi atau kepercayaan yang ada dalam benak konsumen untuk menjadi pembeda dari merek yang lainnya seperti lambang, desain huruf atau warna khusus. Pada tingkat persaingan yang rendah, merek hanya sekedar membedakan antara satu produk dengan produk lainnya atau merek sekedar nama(just a name). Sedangkan pada tingkat persaingan yang tinggi, merek memberikan kontribusi 
dalam menciptakan dan menjaga daya saing sebuah produk. Merek akan dihubungkan dengan citra khusus yang mampu memberikan asosiasi tertentu dalam benak konsumen.

Buchari Alma (2011) mendefinisikan bahwa : "Harga sebagai nilai suatu barang yang dinyatakan dengan uang". Harga memiliki dua peranan utama dalam proses pengambilan keputusan para pembeli, yaitu peranan alokasi dan peranan informasi. Chandra dalam Tjiptono (2014) menyatakan sebagai salah satu elemen bauran pemasaran, harga membutuhkan pertimbangan cermat, sehubungan dengan sejumlah dimensi stratejik harga. Menurut Kotler dan Armstrong terjemahan Sabran (2012), ada empat indikator yang harga yaitu:

1. Keterjangkauan harga

2. Kesesuaian harga dengan kualitas produk

3. Daya saing harga

4. Kesesuaian harga dengan manfaat

Menurut Kotler \& Keller (2009) word of mouth marketing adalah kegiatan pemasaran melalui perantara orang ke orang baik secara lisan, tulisan, maupun lewat alat komunikasi elektronik yang berhubungan internet yang didasari oleh pengelaman atas produk atau jasa. Adapun indikator word of mouth menurut Babin, Barry (2015) sebagai berikut :

1. Kemauan konsumen dalam membicarakan hal - hal positif tentang kualitas pelayanan dan produk kepada orang lain.

2. Rekomendasi jasa dan produk perusahaan kepada orang lain

3. Dorongan terhadap teman atau relasi untuk melakukan pembelian terhadap produk dan jasa perusahaan

Tujuan dari penelitian ini adalah:

1. Untuk mengetahui pengaruh brand image terhadap keputusan pembelian di The Highland Park Resort Hotel Bogor

2. Untuk mengetahui pengaruh persepsi harga terhadap keputusan pembelian di The Highland Park Resort Hotel Bogor.

3. Untuk mengetahui pengaruh komunikasi dari mulut ke mulut (word of mouth communication) terhadap keputusan pembelian di The Highland Park Resort Hotel Bogor.

4. Untuk mengetahui pengaruh Brand Image, Persepsi harga dan Word of mouth terhadap keputusan pembelian di The Highland Park Resort Hotel Bogor.

\section{METODE PENELITIAN}

Metodologi penelitian yang digunakan dalam penelitian ini adalah metode deskriptif dan metode kuantitatif Sumber data yang digunakan dalam penelitian ini adalah data primer dan sekunder. Metode pengumpulan data pada penelitian ini menggunakan kuesioner, yaitu teknik pengumpulan data yang dilakukan dengan cara memberi seperangkat pertanyaan atau pernyataan tertulis kepada responden untuk dijawab. Berkaitan dengan penelitian ini, penulis membuat penelitian dengan menggunakan analisis regresi berganda. Dalam pengolahan data dan kuesioner digunakan alat analisis yaitu Software SPSS Statistic 22.

Lokasi penelitian di daerah Kawasan j1. Curug Nangka, Kp. Sinarwangi, Sukajadi, Kec. Tamansari - Kab. Bogor 16610 Jawa Barat. Penelitian dilakukan mulai pada tanggal 01 Desember 2018 sampai dengan 29 Februari 2019. Populasi penelitian ini adalah pelanggan yang sudah menginap di The Highland Park Resort Bogor. Jumlah sampel penelitian ini adalah:
Tourism Customer

Purchasing

Decision 
Tourism Customer

Purchasing

Decision

$\underline{34}$ $n=\frac{52.652}{\left(52.652 \cdot 0,1^{2}+1\right)}$

$\mathrm{n}=99,81 \rightarrow 100$ orang responden

\section{HASIL DAN PEMBAHASAN}

Analisis Kualitas Data

Tabel 1. Uji Validitas terhadap indicator-indikator variabel

\begin{tabular}{lcccc}
$\begin{array}{c}\text { No } \\
\text { Pernyatan }\end{array}$ & $\begin{array}{c}\text { r-product } \\
\text { moment hitung }\end{array}$ & $\begin{array}{c}\text { r-product } \\
\text { moment tabel } \\
(\mathrm{n}=100 ; \alpha=5 \%)\end{array}$ & Signifikansi & Kesimpulan \\
\hline \multicolumn{2}{l}{ VARIABEL BRAND IMAGE } & & & \\
\hline 1 & 0,814 & 0,196 & 0,000 & Valid \\
2 & 0,855 & 0,196 & 0,000 & Valid \\
3 & 0,831 & 0,196 & 0,000 & Valid \\
Variabel Persepsi Harga & & & \\
1 & 0,826 & 0,196 & 0.000 & Valid \\
2 & 0,731 & 0,196 & 0,000 & Valid \\
3 & 0,876 & 0,196 & 0,000 & Valid \\
4 & 0,840 & 0,196 & 0,000 & Valid \\
Variabel Word of Mouth & & & \\
1 & 0,889 & 0,196 & 0.000 & Valid \\
2 & 0,913 & 0,196 & 0,000 & Valid \\
3 & 0,896 & 0,196 & 0,000 & Valid \\
Variabel Keputusan Pembelian & & & \\
1 & 0,772 & 0,196 & 0.000 & Valid \\
2 & 0,746 & 0,196 & 0,000 & Valid \\
3 & 0,774 & 0,196 & 0,000 & Valid \\
4 & 0,836 & 0,196 & 0,000 & Valid \\
5 & 0,726 & 0,196 & 0,000 & Valid
\end{tabular}

Sumber: Data Hasil Pengolahan Spss, 2019.

Tabel 1 menyatakan bahwa hasil r-product moment hitung untuk pernyataan ke 1 yaitu 0,814 ; pernyataan ke 2 yaitu 0,855 ; dan pernyataa ke 3 yaitu 0,831 . Hasil r-product moment hitung di atas menunjukan hasil lebih besar dari r-product moment tabel, $\mathrm{n}=100, \alpha=5 \%$ yaitu 0,196 dan nilai signifikansi dibawah $5 \%$ sehingga kesimpulannya adalah valid dan dapat digunakan untuk penelitian selanjutnya.

Tabel 1 menyatakan bahwa hasil r-product moment hitung untuk pernyataan ke 1 yaitu 0,826 ; pernyataan ke 2 yaitu 0,731 ; pernyataan ke 3 yaitu 0,876 ; dan pernyataan ke 4 yaitu 0,840; Hasil r-product moment hitung di atas menunjukan hasil lebih besar dari r-product moment tabel, $n=100, \alpha=5 \%$ yaitu 0,196 dan nilai signifikansi dibawah 5\% sehingga kesimpulannya adalah valid dan dapat digunakan untuk penelitian selanjutnya.

Tabel 12 menyatakan bahwa hasil r-product moment hitung untuk pernyataan ke 1 yaitu 0,889; pernyataan ke 2 yaitu 0,913; dan pernyataan ke 3 yaitu 0,896. Hasil r-product moment hitung di atas menunjukan hasil lebih besar dari r-product moment tabel, $\mathrm{n}=100, \alpha=5 \%$ yaitu 0,196 dan nilai signifikansi dibawah $5 \%$ sehingga kesimpulannya adalah valid dan dapat digunakan untuk penelitian selanjutnya. 
Berdasarkan Tabel 1 menyatakan bahwa hasil r-product moment hitung untuk pernyataan ke 1 yaitu 0,772 ; pernyataan ke 2 yaitu 0,746 ; pernyataan ke 3 yaitu 0,774 ; pernyataan ke 4 yaitu 0,836 dan pernyataan ke 5 yaitu 0,726 . Hasil $r$-product moment hitung di atas menunjukan hasil lebih besar dari r-product moment tabel, $\mathrm{n}=100, \alpha=5 \%$ yaitu 0,196 dan nilai signifikansi dibawah $5 \%$ sehingga kesimpulannya adalah valid dan dapat digunakan untuk penelitian selanjutnya. Tabel 2 Uji Reliabilitas Terhadap Variabel X1 (Brand Image), X2 (Persepsi harga), X3 (Word Of Mouth) dan Y (Keputusan Pembelian)

\begin{tabular}{ccc}
\hline Variabel & Cronbach's Alpha & N of item \\
\hline X1 & .741 & 4 \\
\hline X2 & .821 & 5 \\
\hline X3 & .862 & 4 \\
\hline Y & .799 & 6
\end{tabular}

Sumber: Data Hasil Pengolahan Spss, 2019.

Berdasarkan tabel 2 diperoleh hasil Cronbach's Alpha untuk variabel Pengaruh Brand Image sebesar 0,741 dan nilai Cronbach's Alpha lebih besar dari 0,600 maka data dinyatakan reliable, hasil Cronbach's Alpha untuk variabel Persepsi Harga sebesar 0,821 dan nilai Cronbach's Alpha lebih besar dari 0,600 maka data dinyatakan reliable, hasil Cronbach's Alpha untuk variabel Word OfMouth sebesar 0,862 dan nilai Cronbach's Alpha lebih besar dari 0,600 maka data dinyatakan reliabell dan hasil Cronbach's Alpha untuk variabel Keputusan Pembelian sebesar 0,799 dan nilai Cronbach's Alpha lebih besar dari 0,600 maka data dinyatakan reliabel.

Uji Normalitas data dilakukan untuk mengetahui seberapa jauh data yang dikumpulkan mengikuti kaidah-kaidah kurva normal, metode ini dilakukan dalam penelitian dengan menguji apakah ada model regresi, variabel dependen dan independennya mempunyai distribusi normal atau tidak, dengan cara Uji Skewness-Kurtosis. Hasil nilai uji normalitas yang telah dilakukan penelitian pada tabel 3.

Tabel 3 Uji Normalitas data Variabel X1, X2, X3 dan Y

\begin{tabular}{lccc}
\hline & $\mathrm{N}$ & & \\
\cline { 2 - 4 } & Statistic & Skewness & Kurtosis \\
\hline total_X1 & 100 & $-0,12956$ & $-0,82369$ \\
\hline Total_X2 & 100 & 0,818123 & 0,074953 \\
\hline Total_X3 & 100 & $-0,77078$ & $-1,45786$ \\
\hline Total_Y & 100 & $-0,037$ & 0,30359 \\
\hline Valid N (listwise) & 100 & & \\
\hline Sul
\end{tabular}

Sumber: Data hasil pengolahan Spss,2019.

Berdasarkan tabel 3 nilai Test Statistic Asymp.Sig(2-tailed) maka dapat diartikan data berdistribusi normal.

Tabel 4. Tabel Uji Multikolinearitas

Coefficients $^{\mathrm{a}}$

\begin{tabular}{llrr}
\hline \multirow{2}{*}{ Model } & \multicolumn{2}{c}{ Collinearity Statistics } \\
\cline { 2 - 4 } & & Tolerance & VIF \\
\hline \multirow{2}{*}{1} & total_X1 & .578 & 1.729 \\
\cline { 2 - 4 } & Total_X2 & .738 & 1.354 \\
\cline { 2 - 4 } & Total_X3 & .621 & 1.610 \\
\hline
\end{tabular}

a. Dependent Variable: Total_Y

Sumber: Data Hasil Pengolahan Spss, 2019.

Tourism Customer

Purchasing

Decision
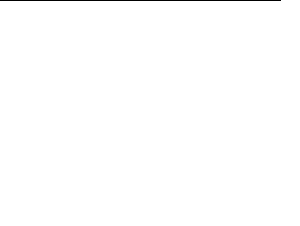
Tourism Customer Purchasing Decision

36

\section{JIPKES}

Jurnal Ilmiah Pariwisata Kesatuan

Vol. 1 No. 1, 2020 pp. $31-42$

BI KESATUAN

E-ISSN XXXX - XXXX DOI:
Uji multikolinearitas bertujuan untuk menguji apakah dalam model regresi ditemukan adanya korelasi antara variabel bebas (independent). Untuk dapat menentukan apakah terdapat multikolinearitas dalam model regresi pada penelitian ini adalah dengan melihat nilai VIF (Variance Inflation Factor) dan Tolerance serta menganalisis matrix korelasi variabel bebas. Adapun nilai toleransi dan VIF dapat dilihat dari tabel 4. Berdasarkan tabel 4. variabel Pengaruh Brand Image (X1) diperoleh nilai toleransi sebesar 0,578 dan nilai VIF sebesar 1,729; Persepsi Harga diperoleh nilai toleransi sebesar 0,738 dan nilai VIF sebesar 1,354 dan variabel Word Of Mouth diperoleh nilai toleransi sebesar 0,621 dan nilai VIF sebesar 1,610. Variabel X1, X2 dan X3 memperoleh nilai VIF dibawah 10 maka tidak terjadi multikolinearitas.

Uji heteroskedastisitas digunakan untuk mengetahui ada atau tidaknya penyimpangan asumsi klasik heteroskedastisitas yaitu adanya ketidaksamaan varian dari residual untuk semua pengamatan pada model regresi. Prasyarat yang harus terpenuhi dalam model regresi adalah tidak adanya gejala heteroskedastisitas.

Tabel 5 Uji Heteroskedastisitas

ANOVAa

\begin{tabular}{llrrrrr}
\hline \multicolumn{2}{l}{ Model } & $\begin{array}{l}\text { Sum of } \\
\text { Squares }\end{array}$ & \multicolumn{1}{c}{ Df } & \multicolumn{1}{c}{$\begin{array}{c}\text { Mean } \\
\text { Square }\end{array}$} & F & \multicolumn{1}{c}{ Sig. } \\
\hline \multirow{2}{*}{1} & Regression & 5.204 & 3 & 1.735 & 1.204 & $.313^{\text {b }}$ \\
\cline { 2 - 7 } & Residual & 138.314 & 96 & 1.441 & & \\
\cline { 2 - 7 } & Total & 143.518 & 99 & & & \\
\hline
\end{tabular}

a. Dependent Variable: absresid

b. Predictors: (Constant), Total_X3, Total_X2, total_X1

\section{Coefficients $^{\mathrm{a}}$}

\begin{tabular}{|c|c|c|c|c|c|c|}
\hline \multirow{2}{*}{\multicolumn{2}{|c|}{ Model }} & \multicolumn{2}{|c|}{$\begin{array}{c}\text { Unstandardized } \\
\text { Coefficients }\end{array}$} & \multirow{2}{*}{$\begin{array}{c}\text { Standardized } \\
\text { Coefficients } \\
\text { Beta }\end{array}$} & \multirow[b]{2}{*}{$\mathrm{T}$} & \multirow[b]{2}{*}{ Sig. } \\
\hline & & $\mathrm{B}$ & Std. Error & & & \\
\hline 1 & (Constant) & 1.097 & 1.121 & & .978 & .330 \\
\hline & total_X1 & .145 & .114 & .168 & 1.274 & .206 \\
\hline & Total_X2 & -.098 & .056 & -.203 & -1.743 & .085 \\
\hline & Total_X3 & -.008 & .083 & -.012 & -.094 & .925 \\
\hline
\end{tabular}

a. Dependent Variable: absresid

Sumber: Data Hasil Pengolahan Spss, 2019.

Berdasarkan tabel 5 diperoleh bahwa semua variabel independen secara statistic baik X1 (Pengaruh Brand Image), X2 (Persepsi Harga), dan X3 (Word Of Mouth) mempunyai nilai signifikan $>0,05$ atau diatas $5 \%$ dengan demikian dapat disimpulkan bahwa tidak terjadi heteroskedastisitas atau bersifat homoskedastisitas.

\section{Analisis Regresi Berganda}

Berdasarkan tabel 6 dapat ditentukan persamaan regresi berganda untuk penelitian ini sebegai berikut:

$\hat{Y}=6,189+-0,016 X_{1}+0,392 X_{2}+0,655 X_{3}+$ error

Berdasarkan persamaan regresi di atas, jika:

a. Pengaruh Brand Image $=$ Persepsi Harga $=$ Word OfMouth $=0$, maka nilai dari Keputusan Pembelian nilainya sebesar 6,189 
b. Jika Pengaruh Brand Image naik sebesar 1 (satu) satuan maka Keputusan Pembelian akan naik sebesar -0,016 jika variabel lain dianggap konstan.

c. Jika Persepsi Harga naik sebesar 1 (satu) satuan maka Keputusan Pembelian akan naik sebesar 0,392 jika variabel lain dianggap konstan.

d. Jika Word Of Mouth naik sebesar 1 (satu) satuan maka Keputusan Pembelian akan naik sebesar 0,655 jika variabel lain dianggap konstan.

Tabel 6 Hasil Analisis Regresi

Coefficients $^{\mathrm{a}}$

\begin{tabular}{|c|c|c|c|c|c|}
\hline \multirow[b]{2}{*}{ Model } & \multicolumn{2}{|c|}{$\begin{array}{l}\text { Unstandardized } \\
\text { Coefficients }\end{array}$} & \multirow{2}{*}{$\begin{array}{c}\begin{array}{c}\text { Standardized } \\
\text { Coefficients }\end{array} \\
\text { Beta } \\
\end{array}$} & \multirow[b]{2}{*}{$\mathrm{t}$} & \multirow[b]{2}{*}{ Sig. } \\
\hline & $\mathrm{B}$ & Std. Error & & & \\
\hline 1 (Constant) & 6.189 & 1.772 & & 3.493 & .001 \\
\hline Brand Image & -.016 & .180 & -.008 & -.087 & .931 \\
\hline $\begin{array}{l}\text { Persepsi } \\
\text { Harga }\end{array}$ & .392 & .089 & .375 & 4.424 & .000 \\
\hline Word OfMouth & .655 & .131 & .462 & 5.002 & .000 \\
\hline
\end{tabular}

a. Dependent Variable: Total_Y

Sumber: Data Hasil Pengolahan Spss, 2019.

Pengaruh antara Pengaruh Brand Image (X1) terhadap Keputusan Pembelian (Y)

\begin{tabular}{ll}
\hline $\begin{array}{l}\text { Hipotesis } \\
\text { penelitian } 1\end{array}$ & $\begin{array}{l}\text { Pengaruh Brand Image mempunyai pengaruh positif } \\
\text { dan signifikan terhadap Keputusan Pembelian }\end{array}$ \\
\hline $\mathrm{H} 0: \beta 1=0$ & $\begin{array}{l}\text { Pengaruh Brand Image tidak mempunyai hubungan } \\
\text { dengan Keputusan Pembelian }\end{array}$ \\
\hline $\mathrm{H} 1: \beta 1 \neq 0$ & $\begin{array}{l}\text { Pengaruh Brand Image mempunyai hubungan dengan } \\
\text { Keputusan Pembelian }\end{array}$ \\
\hline
\end{tabular}

Berdasarkan tabel 6 Pengaruh antara Pengaruh Brand Image (X1) dengan Keputusan Pembelian (Y) diperoleh t hitung sebesar -0.087 dan lebih kecil dari ttabel $(\mathrm{df}=\mathrm{n}-\mathrm{k}-1$ atau $\mathrm{df}=100-3-1=96 ; \alpha=5 \%)=1,66$ dan nilai signifikan $0,017<$ 0,05; H0 diterima dan $\mathrm{H} 1$ ditolak. Kesimpulan hipotesis penelitian pertama diterima, artinya tidak ada pengaruh yang positif dan signifikan antara Pengaruh Brand lmage (X1) dengan Keputusan Pembelian (Y).

Pengaruh antara Persepsi harga (X2) terhadap Keputusan Pembelian (Y)

\begin{tabular}{ll} 
Hipotesis & Persepsi Harga mempunyai pengaruh positif dan \\
penelitian 2 & signifikan terhadap Keputusan Pembelian \\
\hline H0 $: \beta 2=0$ & $\begin{array}{l}\text { Persepsi Harga tidak mempunyai hubungan dengan } \\
\text { Keputusan Pembelian }\end{array}$ \\
\hline $\mathrm{H} 2: \beta 2 \neq 0$ & $\begin{array}{l}\text { Persepsi Harga mempunyai hubungan dengan } \\
\text { Keputusan Pembelian }\end{array}$
\end{tabular}

Berdasarkan tabel 6 Pengaruh antara Persepsi Harga (X2) dengan Keputusan Pembelian (Y) diperoleh t hitung sebesar 4,424 dan lebih besar dari t-tabel $(\mathrm{df}=\mathrm{n}-\mathrm{k}-1$ atau $\mathrm{df}=100-3-1=96 ; \alpha=5 \%)=1,66$ dan nilai signifikan $0,001<0,05$; $\mathrm{H} 0$ ditolak dan $\mathrm{H} 2$ diterima. Kesimpulan hipotesis penelitian kedua diterima, artinya ada pengaruh yang positif dan signifikan antara Persepsi Harga (X2) dengan Keputusan Pembelian (Y).

Berdasarkan tabel 6 Pengaruh antara Word Of Mouth (X3) dengan Keputusan Pembelian (Y) diperoleh t hitung sebesar 5,002 dan lebih besar dari t-tabel $(\mathrm{df}=\mathrm{n}-\mathrm{k}-1$ atau $\mathrm{df}=100-3-1=96 ; \alpha=5 \%)=1,66$ dan nilai signifikan $0,000<0,05$; $\mathrm{H} 0$ ditolak dan $\mathrm{H} 3$ diterima.
Tourism Customer

Purchasing

Decision 
Tourism Customer Purchasing

Decision

38

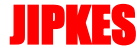

Jurnal Ilmiah Pariwisata Kesatuan

Vol. 1 No. 1,2020

pp. $31-42$

IBI KESATUAN

E-ISSN XXXX - XXXX

DOI:
Pengaruh antara Word Of Mouth (X3) terhadap Keputusan Pembelian (Y) Hipotesis Word Of Mouth mempunyai pengaruh positif dan penelitian 3 signifikan terhadap Keputusan Pembelian $\mathrm{HO}: \beta 3=0$ Word Of Mouth tidak mempunyai hubungan dengan Keputusan Pembelian

$\mathrm{H} 3: \beta 3 \neq 0$ Word Of Mouth mempunyai hubungan dengan Keputusan Pembelian

Kesimpulan hipotesis penelitian ketiga diterima, artinya ada pengaruh yang positif dan signifikan antara Word Of Mouth (X3) dengan Keputusan Pembelian (Y).

Hasil analisis data secara simultan dengan menggunakan program SPSS dapat disajikan dalam tabel sebagai berikut :

Tabel 7 Hasil Uji Simultan (Uji F)

\begin{tabular}{llcc}
\hline Model & F & Sig. \\
\hline 1 & Regression & 30.987 & $.000^{b}$ \\
\cline { 2 - 4 } & Residual & & \\
\cline { 2 - 3 } & Total & & \\
\hline
\end{tabular}

a. Dependent Variable: Total_Y

b. Predictors: (Constant), Total_X3, Total_X2, total_X1

\begin{tabular}{ll}
\hline Hipotesis penelitian 4 & $\begin{array}{l}\text { Pengaruh Brand Image, Persepsi Harga dan } \\
\end{array}$ \\
& Word Of Mouth secara bersama-sama \\
& mempunyai pengaruh positif dan signifikan \\
& terhadap Keputusan Pembelian \\
\hline $\mathrm{H} 0: \beta 1, \beta 2, \beta 3=0$ & Pengaruh Brang Image, Persepsi Harga dan \\
& Word Of Mouth secara bersama-sama tidak \\
& mempunyai hubungan dengan Keputusan \\
& Pembelian \\
\hline $\mathrm{H} 4: \beta 1, \beta 2, \beta 3 \neq 0$ & Pengaruh Brang Image, Persepsi Harga dan \\
& Word Of Mouth secara bersama-sama \\
& mempunyai hubungan dengan Keputusan \\
& Pembelian
\end{tabular}

Berdasarkan tabel 7 hubungan antara Pengaruh Brang Image, Persepsi Harga dan Word Of Mouth secara bersama-sama tidak mempunyai hubungan dengan Keputusan Pembelian, diperoleh f-hitung 30.987 dan lebih besar dari f-tabel $(\mathrm{df} 1=4, \mathrm{df} 2=98, \alpha=5 \%)=2,70$; dan didukung oleh nilai signifikansi sebesar 0,000 dan lebih kecil dari $(\alpha=5 \%)=0,05$ dengan demikian $\mathrm{H} 0$ ditolak dan $\mathrm{H} 4$ diterima, Pengaruh Brand Image, Persepsi Harga dan Word Of Mouth secara simultan terhadap Keputusan Pembelian, maka hipotesis 4 diterima.

\section{Analisis Korelasi}

Untuk melihat adanya hubungan antara variable Pengaruh Brand Image, Persepsi Harga dan Word Of Mouth terhadap Keputusan Pembelian serta keeratan hubungannya maka dilakukan analisis korelasi. Hasil analisis dari korelasi adalah koefisien korelasi yang menunjukkan kekuatan dan kelemahan dari suatu hubungan. Sedangkan untuk membuktikan ada tidaknya pengaruh antar variabel, akan dilakukan analisis regresi secara simultan untuk masing-masing variabel pada masing-masing variabel. 
Correlations

\begin{tabular}{llrrrr}
\hline & & Total_Y & total_X1 & Total_X2 & \multicolumn{1}{c}{ Total_3 } \\
\hline Pearson & & 1.000 & .448 & .565 & .615 \\
Correlation & Total_Y & .448 & 1.000 & .484 & .597 \\
\cline { 2 - 6 } & total_X1 & .565 & .484 & 1.000 & .422 \\
\cline { 2 - 6 } & Total_X2 & .615 & .597 & .422 & 1.000 \\
\cline { 2 - 6 } & Total_X3 &. & .000 & .000 & .000 \\
\hline Sig. (1-tailed) & Total_Y & .000 &. & .000 & .000 \\
\cline { 2 - 6 } & total_X1 & .000 & .000 & .000 \\
\cline { 2 - 6 } & Total_X2 & .000 & .000 & .000 & \\
\cline { 2 - 6 } & Total_X3 & 100 & 100 & 100 & 100 \\
\hline N & Total_Y & 100 & 100 & 100 & 100 \\
\cline { 2 - 6 } & total_X1 & 100 & 100 & 100 & 100 \\
\cline { 2 - 6 } & Total_X2 & 100 & 100 & 100 & 100 \\
\cline { 2 - 6 } & Total_X3 & & & & \\
& & &
\end{tabular}

Sumber: Data Hasil Pengolahan Spss, 2019.

Hasil Uji Korelasi :

1. Berdasarkan Tabel 8 menunjukkan bahwa variabel Pengaruh Brand Image (X1) berkorelasi positif sebesar 0,484 terhadap variable Persepsi Harga (X2), dapat disimpulkan kedua variabel tersebut terdapat korelasi yang signifikan antara variabel yang dihubungkan.

2. Berdasarkan Tabel 8 menunjukkan bahwa variable Pengaruh Brand Image (X1) berkorelasi positif sebesar 0,597 terhadap variable Word Of Mouth (X3), dapat disimpulkan kedua variabel tersebut terdapat korelasi yang signifikan antara variabel yang dihubungkan.

3. Berdasarkan Tabel 8 menunjukkan bahwa variabel Pengaruh Brand Image (X1) berkorelasi positif sebesar 0,448 terhadap variable Keputusan Pembelian (Y), dapat disimpulkan kedua variabel tersebut terdapat korelasi yang signifikan antara variabel yang dihubungkan.

4. Berdasarkan Tabel 8 menunjukkan bahwa variabel Persepsi Harga (X2) berkorelasi positif sebesar 0,422 terhadap variabel Word Of Mouth (X3) dapat disimpulkan kedua variabel tersebut terdapat korelasi yang signifikan antara variabel yang dihubungkan.

5. Berdasarkan Tabel 8 menunjukkan bahwa variabel Persepsi Harga (X2) berkorelasi positif sebesar 0,565 terhadap Keputusan Pembelian (Y) dapat disimpulkan kedua variabel tersebut terdapat korelasi yang signifikan antara variabel yang dihubungkan.

6. Berdasarkan Tabel 8 menunjukkan bahwa variabel Word Of Mouth (X3) berkorelasi positif sebesar 0,615 terhadap variabel Keputusan Pembelian (Y) dapat disimpulkan kedua variabel tersebut terdapat korelasi yang signifikan antara variabel yang dihubungkan.

\section{Koefisien Determinasi}

Nilai koefisien determinasi mencerminkan seberapa besar peran atau kontribusi dari variabel independen terhadap variabel dependen, atau bisa juga dikatakan bahwa variabel independen mampu menjelaskan variabilitas atau keragaman dari variabel dependen
Purchasing

Decision

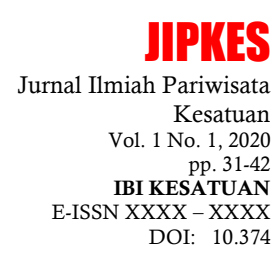


Tourism Customer

Purchasing

Decision

40

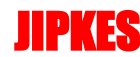

Jurnal Ilmiah Pariwisata

Kesatuan

Vol. 1 No. 1,2020

pp. 31-42

IBI KESATUAN

E-ISSN XXXX - XXXX

DOI:
Tabel 9 Koefisien Korelasi dan Determinasi

Model Summary

\begin{tabular}{llrrr}
\hline Model & R & R Square & Adjusted R Square & Std. Error of the Estimate \\
\hline 1 & $.701^{\text {a }}$ & .492 & .476 & 1.897 \\
\hline
\end{tabular}

a. Predictors: (Constant), Total_X3, Total_X2, total_X1

Sumber: Data Hasil Pengolahan Spss, 2019.

Berdasarkan pada tabel 9 dapat dijelaskan bahwa hubungan atau korelasi berganda pada seluruh variabel (Pengaruh Brand Image, Persepsi Harga, Word of Mouth dan Keputusan Pembelian), memiliki kekuatan hubungan yang sangat kuat. Hal ini dilihat berdasarkan nilai koefisien korelasi berganda sebesar 0,701. Perolehan nilai $r$-square sebesar 0,492 dapat dijelaskan bahwa variabel Pengaruh Brand Image, Persepsi Harga, Word Of Mouth dan Keputusan Pembelian mampu mempengaruhi atau menjelaskan keragaman (variabilitas) nilai dari minat pembelian sebesar 49,2\% sedangkan sisanya sebesar 50,8\% dipengaruhi atau dijelaskan oleh faktor lain atau variabel lain yang tidak diteliti.

\section{Pembahasan}

Berdasarkan hasil kuesioner dan pengolahan data kuesioner menggunakan program SPSS yang telah dilakukan, maka pembahasan terhadap hipotesis penelitian sebagai berikut : Penelitian ini berdasarkan hasil uji statistik di atas hipotesis pertama yang berbunyi terdapat hubungan antara pengaruh Brand Image terhadap Keputusan Pembelian dapat diterima, hal ini ditunjukan dengan nilai thitung sebesar -0,087 yang dimana lebih kecil dibandingkan t-tabel 1,66 dan didukung oleh nilai signifikansi 0,931 lebih besar dibandingkan 0,05. Berdasarkan hasil uji analisis regresi berganda variabel X1 (Brand Image) sebesar -0,016 artinya jika variabel Brand Image naik sebesar satu satuan maka Y (Keputusan Pembelian) akan naik sebesar -0,016 jika variabel lain dianggap konstan. Dengan hasil dimana variabel tersebut tidak berpengaruh positif dan signifikan terhadap Keputusan Pembelian maka Hipotesis 1 ditolak.

Penelitian ini berdasarkan hasil uji statistik di atas hipotesis kedua yang berbunyi terdapat hubungan antara pengaruh Persepsi Harga terhadap Keputusan Pembelian dapat diterima, hal ini ditunjukan dengan nilai t-hitung sebesar 4,424 yang dimana lebih besar dibandingkan t-tabel 1,66 dan didukung oleh nilai signifikansi 0,000 lebih kecil dibandingkan 0,05. Berdasarkan hasil uji analisis regresi berganda variabel X2 (Persepsi Harga) sebesar 0,392 artinya jika variabel Persepsi Harga naik sebesar satu satuan maka Y (Keputusan Pembelian) akan naik sebesar 0,392 jika variabel lain dianggap konstan. Dengan hasil dimana variabel tersebut berpengaruh positif signifikan terhadap Keputusan Pembelian, maka Hipotesis 2 diterima.

Penelitian ini berdasarkan hasil uji statistik di atas hipotesis ketiga yang berbunyi terdapat hubungan antara Word of Mouth terhadap Keputusan Pembelian dapat diterima, hal ini ditunjukan dengan nilai t-hitung sebesar 5,002 yang dimana lebih besar dibandingkan t-tabel 1,66 dan didukung oleh nilai signifikansi 0,000 lebih kecil dibandingkan 0,05. Berdasarkan hasil uji analisis regresi berganda variabel X3 (Word Of Mouth) sebesar 0,655 artinya jika variabel Word OfMouth naik sebesar satu satuan maka Y (Keputusan Pembelian) akan naik sebesar 0,655 jika variabel lain dianggap konstan. Dengan hasil dimana variabel tersebut berpengaruh signifikan terhadap Keputusan Pembelian, maka Hipotesis 3 diterima.

Penelitian ini berdasarkan hasil uji statistik diatas hipotesis keempat yang berbunyi terdapat hubungan antara Pengaruh Brand Image, Persepsi Harga dan 
Word Of Mouth terhadap Keputusan Pembelian dapat diterima, hal ini ditunjukan dengan nilai f-hitung sebesar 30,987 yang dimana lebih besar dibandingkan f-tabel 2,70 dan didukung oleh nilai signifikansi 0,000 lebih kecil dibandingkan 0,05 yang dimana variable Brand Image, Persepsi Harga dan Word Of Mouth secara bersamasama berpengaruh signifikan terhadap Keputusan Pembelian, maka Hipotesis 4 diterima.

Perolehan nilai R Square sebesar 0,492 dijelaskan bahwa variable Brand Image, Persepsi Harga dan Word Of Mouth memengaruhi atau menjelaskan variabilitas nilai dari Keputusan Pembelian sebesar 49,2\%. Sedangkan sisanya 50,8\% dipengaruhi atau dijelaskan oleh variabel lain yang tidak diteliti. Dan dari pengujian simultan Signifikan pada tabel 4.20 dapat diketahui bahwa nilai $\mathrm{F}$ hitung dari keseluruhan variabel adalah sebesar 30,987 sedangkan $\mathrm{F}$ tabelnya sebesar 2,70 yang artinya $\mathrm{F}$ hitung lebih besar dari $\mathrm{F}$ tabel sehingga $\mathrm{H} 0$ ditolak dan H4 diterima. Sehingga dapat disimpulkan bahwa Pengaruh Preferensi Brand Image (X1), Persepsi Harga (X2) dan Word Of Mouth (X3) berpengaruh secara langsung terhadap variabel Keputusan Pembelian (Y) dan signifikan.

\section{PENUTUP}

Di bagian akhir ini peneliti akan membahas kesimpulan yang diambil dari hasil penelitian

1. Brand Image berpengaruh positif dan signifikan terhadap Keputusan Pembelian di The Highland Park Resort Hotel Bogor dengan nilai koefisien regresi sebesar 0,087 dan memiliki nilai signifikan sebesar 0,931.

2. Persepsi Harga berpengaruh positif dan signifikan terhadap Keputusan Pembelian di The Highland Park Resort Hotel Bogor nilai koefisien regresi sebesar 0,392 dan memiliki nilai signifikan sebesar 0,000.

3. Word of Mouth berpengaruh positif dan signifikan terhadap Keputusan Pembelian di The Highland Park Resort Hotel Bogor dengan nilai koefisien regresi sebesar 0,655 dan memiliki nilai signifikan sebesar 0,000.

4. Pengaruh Brand Image, Persepsi Harga, dan Word Of Mouth berpengaruh positif dan signifikan terhadap Keputusan Pembelian di The Highland Park Resort Hotel Bogor dengan nilai $\mathrm{F}$ hitung sebesar 30,987 dan lebih besar dibandingkan dari $F$ tabel sebesar 2,70 dengan nilai signifikansi sebesar 0,000. Artinya semakin baik Brand Image, Persepsi Harga, dan Word Of Mouth, maka Keputusan Pembelian semakin tinggi.

\section{DAFTAR PUSTAKA}

Ajmi, D.N. and Iriyadi, I., 2018. Analisis Penentuan Tarif Rawat Inap dan Perhitungan Harga Pokok Pada Klinik Utama Rawat Inap dr. Yati Zarnudji. Jurnal Ilmiah Akuntansi Kesatuan, 6(3), pp.227-238.

Alma, Buchari. 2014. Manajemen Pemasaran dan Pemasaran Jasa. Bandung : Alfabeta

Andy, Sernovitz. 2010. Word OfMouth Marketing : How Smart Companies Get People Talking (Resived Edition). New York : Kaplan Publishing.

Angipora, M P. 2002. Dasar-dasar Pemasaran. PT Raja Grafindo Persada, Jakarta

Augusty Ferdinand. 2011, Metode Penelitian Manajemen Pedoman Penelitian untuk Penulisan Skripsi, Tesis, dan Disertasi Ilmu Manajemen, Edisi 3, AGF Books, Fakultas Ekonomika dan Bisnis Universitas Diponegoro, Semarang.

Daryanto, 2011. Manajemen Pemasaran: Sari Kuliah, Bandung : Satu Nusa
Tourism Customer

Purchasing Decision 
Tourism Customer Purchasing

Decision

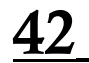

Ferrinadewi, Erna. (2008). Merek dan Psikologi Konsumen. Yogyakarta: Graha Ilmu.

Ghozali, Imam. 2013. Aplikasi Analisis Multivariate dengan Program SPSS Edisi Ketujuh, Semarang : Badan Penerbitan Universitas Diponegoro

Harini. 2008. Penetapan Harga ,Makro Ekonomi Pengantar, Pt Gramedia

Iriyadi, I., 2019. Prevention of Earnings Management through Audit Committee and Audit Quality in the Award-Winning and Non-Winning Companies. Journal of Accounting Research, Organization and Economics, 2(2), pp.155-169.

Kotler, Philip and Kevin Lane Kelller, 2016. Marketing Managemen, $15^{\text {th }}$ Edition, Pearson Education, Inc

Mulyana, M., Hidayat, L. and Puspitasari, R., 2019. Mengukur Pengetahuan Investasi Para Mahasiswa Untuk Pengembangan Galeri Investasi Perguruan Tinggi. JAS-PT (Jurnal Analisis Sistem Pendidikan Tinggi Indonesia), 3(1), pp.3152 .

Munawar, A., Syarif, R. and Morita, M., 2019. Persepsi Mahasiswa Atas Galeri Investasi Perguruan Tinggi dan Pengaruhnya Terhadap Minat Berinvestasi. JAS-PT (Jurnal Analisis Sistem Pendidikan Tinggi Indonesia), 3(2), pp.89-96.

Purba, J.H., 2001. Model Ekonometrika Kelapa Sawit Indonesia, Analisis Simulasi Kebijakan Internal dan Eksternal. Jurnal Kopertis Wilayah, 4, p.12.

Santrock, J.W, 2008. Educational Psychology, $3^{\text {rd }}$ edition, New York : Mcgraw_hill Conpanies

Santoso, Singgih.2010. Statistik Parametrik, Konsep dan Aplikasi dengan SPSS. Cetakan Pertama, PT Elex Media Komputindo, Jakarta, PT Gramedia, Jakarta.

Sumardy, 2011. The Power Of Word Of Mouth Marketing, Jakarta

Surachman. 2008. Dasar-Dasar Manajemen Merek (Alat Pemasaran Untuk Memenangkan Persaingan). Malang: Bayumedia Publishing

Tjiptono, Fandy, 2015. Strategi Pemasaran, Edisi 4, Penerbit Andi, Yogyakarta

Voss, Chriss, dan Arnold Giroud. 2000. Customer Benefit and Company Consequens of Customer Salesperson Relationship in Retailing.Journal of Personal and Sales Management.

Yazid, 2008, Pemasaran Jasa, Edisi Kedua, Yogyakarta : Ekonisia Kampus Fakultas Ekonomi UII.

Anwar, A., dan Gulzar, A. (2011). Exploring The Mediating Role of Customer Loyalty on The Relationship Between Brand Affect, Brand Quality, Brand Personality, And Customers' Brand Extension Attitude In Fashion Wear. International Journal of Economics and Management Sciences, Vol. 1, No. 5

Babin, Barry, 2015. Modeling Consumer Statisfaction and Word Of Mouth: Restaurant Partronage In Korea, The Journal Of Service Marketing : Vol 19 No. 3 hal 133-139

Katika Sari, Ratna Dwi. (2012). Analisis Pengaruh Kualitas Produk, Persepsi Harga, dan Word Of Mouth Communication Terhadap Keputusan Pembelian Mebel pada CV. Mega Jaya Mebel Semarang. Skripsi Fakultas Ekonomi dan Bisnis Universitas Diponegoro : Tidak diterbitkan.

JIPYES

Jurnal Ilmiah Pariwisata Kesatuan

Vol. 1 No. 1,2020

pp. $31-42$

IBI KESATUAN

E-ISSN XXXX - XXXX

DOI:
Krisna Gede, Indra Jaya \& Nurhadi, MM "Pengaruh Citra Merek, Kualitas Produk, Persepsi Harga dan Word Of Mouth Terhadap Minat Beli Studi Kasus pada Mahasiswa Fakultas Ekonomi UNY Pengguna Iphone. 